\title{
MODEL STRUCTURE AND THE COMBINED WELFARE AND TRADE EFFECTS OF CHINA'S TRADE RELATED POLICIES
}

\author{
Yan Dong \\ John Whalley \\ Working Paper 15363 \\ http://www.nber.org/papers/w15363 \\ NATIONAL BUREAU OF ECONOMIC RESEARCH \\ 1050 Massachusetts Avenue \\ Cambridge, MA 02138 \\ September 2009
}

We are grateful to the Ontario Research Fund (ORF-3), CIGI, and the Social Sciences and Humanities Research Council for financial support. The views expressed herein are those of the author(s) and do not necessarily reflect the views of the National Bureau of Economic Research.

NBER working papers are circulated for discussion and comment purposes. They have not been peerreviewed or been subject to the review by the NBER Board of Directors that accompanies official NBER publications.

(C) 2009 by Yan Dong and John Whalley. All rights reserved. Short sections of text, not to exceed two paragraphs, may be quoted without explicit permission provided that full credit, including $\odot$ notice, is given to the source. 
Model Structure and the Combined Welfare and Trade Effects of China's Trade Related Policies Yan Dong and John Whalley

NBER Working Paper No. 15363

September 2009

JEL No. F1

\begin{abstract}
$\underline{\text { ABSTRACT }}$
Because China's economic structure is different from that in OECD countries, using conventional neo-classical competitive trade models to analyze the welfare and trade impacts of trade related policy change can be misleading. In particular, both the exchange rate regime and output and pricing policies of state owned enterprises (SOE's) will have effects on trade and welfare which differ from a classical competitive model. This paper present a numerical model that captures the combined and interactive effects of three policy elements in prototype form of tariffs, policy towards SOEs in the industrial sector, and an exchange rate regime supporting large trade surpluses and additions to foreign reserves. The model has non neutral monetary features, endogenous trade imbalances and average product pricing of labor in goods. We do not claim it to be fully representative of modern China, but it does go some way beyond simple competitive models used elsewhere and points to different conclusions of policy impact. We calibrate our model to 2006 data, and then evaluate the impacts both singly and in combination of: tariff liberalization, a move to more freely floating exchange rates, and SOE enterprise reform. Results show that large differences in policy impacts relative to a classical competitive model. SOE reform and a freely floating Chinese exchange rate have more impact on China's welfare than tariff liberalization. Policies of RMB appreciation and increasing China's money stock reduce China's trade surplus. In the traditional competitive model, trade liberalization impacts both imports and exports, while in our central case model, with endogenously determined trade surplus, trade liberalization has little effect on exports. Most of the policy impact is on imports and the trade surplus. SOE reform of China's manufacturing sector significantly decreases production of China's manufacturing sector and increases production in China's other sectors.
\end{abstract}

\author{
Yan Dong \\ Institute of World Economics and Politics \\ Chinese Academy of Social Sciences \\ 15th Floor of CASS Building \\ No.5 Jianguomen Nei Avenue \\ Beijing, China, 100732 \\ dongyan@cass.org.cn \\ John Whalley \\ Department of Economics \\ Social Science Centre \\ University of Western Ontario \\ London, Ontario N6A 5C2 CANADA \\ and NBER \\ jwhalley@uwo.ca
}




\section{Introduction}

The center piece of Western neo-classical economic analysis is the Arrow-Debreu competitive equilibrium model. It has been used in numerical form to describe both Western and Chinese economies despite China’s economy being quite different in structure. Notably China is in transition from a central-planned economy to a market economy, and other elements complicate analysis, such as SOEs , and the exchange rate regime. Here, we present a calibrated numerical model of China with SOE production, non neutral monetary and exchange rate structure, and analyze the impacts of different liberalization policies, not only tariff liberalization, but also RMB appreciation and SOE reform, either singly or in combination. Our conclusion is that using simple competitive trade models with ad-valorem tariff equivalent representation of all policies can be misleading.

In the model, for the manufacturing SOE sector, we use a version of the managerial control model of SOEs in Whalley \& Zhang(2006) and Fosse \& Raimondos-Møller(2009), in which SOEs are assumed to be under managerial control with managers politically appointed. Capital is assumed allocated freely to the SOE by credit rationing with a state bank recapitalization mechanism covering any losses. We assume that enterprise managers maximize personal gain from networking and political connections, and enterprise managers maximize enterprise size rather than profits. The implication is that if managers hire labour in a competitive labour market (a strong but greatly simplifying assumption for the Chinese case) and pay labour its going wage, they will hire labour up to the point that the product price equals the average value product of labour, rather than the marginal value product as in the competitive case. We also add monetary structure into a trade model, as in Wang \& Whalley(2007), to reflect a managed Chinese exchange rate and monetary regime with a peg and RMB inconvertibility. Monetary policy is thus non accommodative to the chosen fixed exchange rate, and this implies either excess supply of foreign exchange which the Central Bank accommodates as additions to reserves .

We calibrate this model to 2006 base year data for two countries, China and the Rest of the World. Our base case includes 2006 trade, production, and consumption and constructed 
money supply data. We then use the calibrated model to simulate the impacts of the 3 types of policy change on welfare, trade flows, the trade surplus and production. These cover tariff liberalization, exchange rate and monetary policy (Renminbi appreciation and /or increases in the money stock), and SOE reform.

Results show that tariff liberalization increases imports but has no impact on exports and is welfare improving as the surplus falls. The results for RMB appreciation and monetary policy have effects on exports but are small and reduce trade imbalances and are also welfare improving.SOE reform only has significant trade and welfare impacts in the absence of monetary non neutralities.

Most of the available literature on Chinese SOEs uses econometric models with no explicit trade and monetary structure, assessing the performance, profitability and labor hiring (examples are Bigsten, Liu, and Zhang (2002), Cull and Xu (2003), and Liu (2002)). And while there is literature analyzing interactions between trade structure and monetary policy, they use tariff equivalents and analyze trade policy changes either ignoring monetary structure(such as IMF(2005), Wilenbockel(2006)), or trade impacts of exchange rate changes in structures where trade pattern changes do not follow from a trade model (such as Park(2005),Kamada \&Takagawa(2005),Marquez \& Schindler(2006)). 


\section{A Prototype Model Capturing Some Key Chinese Features}

We analyze the potential impacts of different liberalization policies, tariff liberalization, RMB appreciation, and SOE reform, using a calibrated numerical general equilibrium model of China with SOE production and monetary structure. For the SOE manufacturing sector, we use the managerial control model of SOEs used in Whalley \& Zhang(2006) and Fosse \& Raimondos-Møller(2009). In this SOEs are assumed to be under managerial control with managers politically appointed. Capital is assumed allocated to the SOE by credit rationing, with an assumed state bank recapitalization mechanism which covers any losses. In effect, capital is freely allocated. This more accurately reflects China in the 1980's and early 1990's more so than today, but is analytically tractable and significant elements of this structure remain. We assume that enterprise managers maximize personal gain from networking and political connections and hence that enterprise managers maximize enterprise size rather than profits. The implication is that if managers hire labour in a competitive labour market (a strong simplifying assumption) and pay labour its going wage, they will hire labour up to the point that the product price equals the average value product of labour, rather than the marginal value product as in the competitive case.

On the monetary side we follow Wang \& Whalley (2007), and specify a simple monetary regime in a model with monetary non-neutralities. In this, monetary policy is non accommodative to the chosen fixed exchange rate, and given the current Renminbi peg this implies excess supply of foreign exchange which the Central Bank simply accumulates as reserves.

More formally, the model incorporates 2 countries (China and ROW) indexed by $j$ or $k$ ( $j=1,2, k=1,2$ ) to denote country and 2 traded goods (manufactures and other indexed $i(i=1,2)$ to denotes goods. Goods across countries are heterogeneous (the Armington assumption). 
For each good $i$ produced in country $k$, we define the seller's price (net of tariff) as $P_{i}^{k}$, and allow each country $j$ to impose tariffs at rate $t_{j i}^{k}$ ( country $j$ 's tariff on good $i$ imported from country $k$ ) on each imported good. Tariffs are set to zero for exports. Internal (gross of tariff ) prices for good $i$ produced in country $k$ are thus

$$
P_{j i}^{k}=\left[1+t_{j i}^{k}\right] P_{i}^{k}
$$

On the production side in country 1 (China), we consider a SOE manufacturing sector and a competitive other sector. Both sectors have decreasing returns production functions, with labor as the variable input. Capital used by the SOEs is fixed to reflect capital allocated to this sector by rationed credit and is unpriced with average product pricing of labor. Capital used in the other sector receives a rental return since it is immobile intersectorally.

In the SOE sector, the production function is

$$
Y_{M}^{1}=\varphi_{M}^{1}\left(L_{M}^{1}\right)^{\alpha_{M}^{1}}
$$

where $Y_{M}^{1}$ is manufacturing output in country $1, L_{M}^{1}$ is labour used in manufacturing, $\varphi_{M}^{1}$ is a units term(scalar parameter), and $\alpha_{M}^{1}<1$ is the production exponent.

The use of capital by the SOE is captured by a fixed factor. Capital is assumed to be allocated via centralized credit allocation through the state banking system, but recipients of loans (and hence capital) expect that any servicing costs of the loan will be covered by state bank recapitalization of losses. We assume managers of the enterprise are politically appointed and are concerned with the size of their personal network rather than profits, and networking benefits are collinear with the size of the enterprise they manage. In this simple model with a single SOE, labour is paid its average value product since managers maximize enterprise size measured by output $Y_{M}^{1}$ subject to the enterprise budget constraint.

Since capital is effectively unpriced, this implies that

$$
P_{M}^{1} Y_{M}^{1}=w_{M}^{1} L_{M}^{1}+R_{M}^{1}
$$

that is $\quad w_{M}^{1}=\frac{P_{M}^{1} Y_{M}^{1}-R_{M}^{1}}{L_{M}^{1}}$ 
where $R_{M}^{1}$ is any surplus required to be transferred to the state by the SOE. This, in turn, implies that labour receive its average value product plus its share of required surplus rather than its marginal product, and that implies that conditions for Pareto efficiency are violated.

In the other sector, the production function is

$$
Y_{O}^{1}=\varphi_{O}^{1}\left(L_{O}^{1}\right)^{\alpha_{O}^{1}}
$$

Where $Y_{O}^{1}$ is output in the other sector in country $1, L_{O}^{1}$ is labour used in the other sector, $\varphi_{O}^{1}$ is a units term(scalar parameter), and $\alpha_{O}^{1}<1$ is the production exponent. We assume that in this sector labour is paid its marginal product, i.e. the wage rate is

$$
w_{O}^{1}=P_{O}^{1} \frac{\partial Y_{O}^{1}}{\partial L_{O}^{1}}=\varphi_{O}^{1} P_{O}^{1} \alpha_{O}^{1}\left(L_{O}^{1}\right)^{\alpha_{O}^{1}-1}
$$

and the residual return $\left(P_{O}^{1} Y_{O}^{1}-w_{O}^{1} L_{O}^{1}\right)$ accrues as rent to already invested capital.

In country 2 (rest of the world), the production functions are:

$$
Y_{i}^{2}=\varphi_{i}^{2}\left(L_{i}^{2}\right)^{\alpha_{i}^{2}}(i=M, O)
$$

The $Y_{i}^{2}$ are manufacturing output and other sector output in country $2, L_{i}^{2}$ are labour used in manufacturing sector and other sector, $\varphi_{i}^{2}$ are units terms (scalar parameters), and $\alpha_{i}^{2}<1$ is the production exponent. We assume that in both sectors labour is paid its marginal product, i.e. the wage rate is

$$
w^{2}=P_{i}^{2} \frac{\partial Y_{i}^{2}}{\partial L_{i}^{2}}=\varphi_{i}^{2} P_{i}^{2} \alpha_{i}^{2}\left(L_{i}^{2}\right)^{\alpha_{i}^{2}-1} \quad(i=M, O)
$$

On the demand side of the model, final demands for commodities in country 1 and country 2 as modeled are derived from maximization of CES nested utility functions defined over composites of similar domestically produced and imported goods subject to country budget constraints. This Armington structure allows us to directly incorporate substitution elasticity parameters into the model as the substitution elasticity between similar domestic and imported goods which can then be directly related to import demand elasticities.

Unlike in a conventional trade model, we incorporate endogenously determined trade surpluses and deficits directly into the two country budget constraints. To do this we use a 
simple monetized extension to a pure barter trade model with a transactions demand for money and unitary velocity of circulation. We assume that the surplus country is predetermined as country 1 (China) and the deficit country as country 2 (the rest of the world), and Country 1 fixes its exchange rate and has non-accommodative monetary policy. Country 2 is assumed to fix its money stock to accommodate its trade deficit. This implies that jointly countries 1 and 2 set relative money stocks consistent with the fixed country 1 exchange rate and trade surplus, but monetary non neutralities result. A change in the fixed exchange rate changes both trade flows and country 1's surplus.

Maximizing country 1's utility yields demands from the solution to a 2 stage budgeting problem, ie:

$$
\begin{aligned}
& \max U_{1}\left\{C_{1}\left(D_{i}^{11}, D_{i}^{12}\right)\right\} \\
& \text { St } \sum_{i} P_{1 i}^{1} D_{i}^{11}+\sum_{i} \bar{e} P_{1 i}^{2} D_{i}^{12}=I_{1} \\
& I_{1}=\sum_{i} P_{i}^{1} Y_{i}^{1}-\bar{e} S+T R_{1}+R_{1}
\end{aligned}
$$

where $C_{1}$ is the CES composite of domestic demand and imports in country $1, D_{i}^{11}\left(D_{i}^{12}\right)$ is the demand in country 1 for good $i$ produced in country 1 (2), and $\bar{e}$ is the fixed exchange rate, $S$ is the trade surplus of country $1, T R_{1}$ is the tariff revenue in country 1 , and $R_{1}$ are transfers to the state by the SOE in country 1 . These are assumed recycled to consumers as lump sum transfers.

Country 2's demands are similarly derived by maximizing a nested CES utility function defined over CES composites of imported goods from country 1 and domestically produced goods, i.e.

$$
\begin{gathered}
\max U_{2}\left\{C_{2}\left(D_{i}^{22}, D_{i}^{21}\right)\right\} \\
\text { St } \sum_{i} P_{2 i}^{2} D_{i}^{22}+\sum_{i} \bar{e} P_{2 i}^{1} D_{i}^{21}=I_{2} \\
I_{2}=\sum_{i} P_{i}^{2} Y_{i}^{2}+T R_{2}+S
\end{gathered}
$$


We assume each country's money supply is fixed at $\bar{m}_{1}$ and $\bar{m}_{2}$, and for simplicity, each country has a constant unit velocity transactions demand for money. In equilibrium, this implies:

$$
\begin{gathered}
\sum_{i} P_{i}^{1} D_{i}^{11}+\sum_{i} P_{i}^{1} D_{i}^{21}=\bar{m}_{1} \\
\text { and } \sum_{i} P_{i}^{2} D_{i}^{22}+\sum_{i} P_{i}^{2} D_{i}^{12}+S=\bar{m}_{2}
\end{gathered}
$$

since the surpluses of country 1 implies money holding in the currency of 2 (\$)

Adding demand supply equalities in goods gives

$$
\begin{array}{ll}
D_{i}^{11}+D_{i}^{21}=Y_{i}^{1} & (i=M, O) \\
D_{i}^{22}+D_{i}^{22}=Y_{i}^{2} & (i=M, O)
\end{array}
$$

and factor market clearing conditions

$$
\begin{aligned}
& L_{M}^{1}+L_{O}^{1}=L^{1} \\
& L_{M}^{2}+L_{O}^{2}=L^{2}
\end{aligned}
$$

In equilibrium, factor prices are equalized across the two sectors in country 2, and wage rates are equalized across the two sectors in each country, i.e.

$$
\begin{aligned}
& w_{A}^{1}=w_{M}^{1} \\
& w_{A}^{2}=w_{M}^{2}
\end{aligned}
$$

and sellers commodity prices clear goods markets. These prices are consistent with zero profit conditions in country 2 and SOE pricing the determination of rent in the other section in country 1.

We can build a model admissible data set for 2006 for this structure which we use to determine model parameters through calibration and then perform counterfactual experiments for changes in different policy elements. Alternative equilibria can easily be computed for this system. 


\section{Data and Model Calibration}

We build a model compatible benchmark general equilibrium data set which we use in calibration. We use a base year of 2006 . The two countries in our simulations are China and the Rest of the World. Our base case data includes 2006 trade, production, consumption and country money supply data constructed to equal the value of transactions assuming unitary velocity.

In the model, for simplicity, we treat the entire manufacturing sector as a single SOE. This is a strong assumption which ignores China's growing private manufacturing sector and the role of inward FDI flows. It is adopted as a simplification for purposes of tractability. The whole Chinese manufacturing sector is also treated as producing a single product. We define physical units for both manufacturing and the other sector product to be related to value observations from national accounts following the Harberger(1962) and Shoven \& Whalley(1972) units convention that in the initial benchmark equilibrium data world prices are unity, i.e. $P_{M}^{1}=P_{M}^{2}=P_{O}^{1}=P_{O}^{2}=1$, and factor prices are unity, i.e. $w_{M}^{1}=w_{M}^{2}=w_{O}^{1}=w_{O}^{2}=1$.

To convert Chinese data into units consistent with the ROW data in \$, we construct an artificial Chinese currency unit, $R M B^{*}$, which we set as $R M B^{*}=7.972 R M B$, which is the exchange rate of the US dollar to Renminbi in 2006. This implies that 1 unit of $R M B^{*}$ equals 1 US dollar. This convention is adopted so that in calibration all equilibrium prices will be unity for both Chinese and ROW goods and factors.

In Table 1 ,GDP data is from the World Bank's WDI database and trade data is taken from the UNCOMTRADE database. F.o.b. exports values as reported by exporting countries are used, China's exports and imports are taken as imports and exports by the rest of the world from and to China. These trade data , in turn, imply China's trade surplus for 2006. Labor input data is from China's NBS data and from the U.S. Bureau of Labor of Statistics. We assume the labor input of ROW is 4 times that of U.S. on the basis that U.S. GDP is roughly $1 / 4$ of world GDP China. Tariff data is from the WTO Statistical Database, and for 2006, the average tariff on China's manufactured import was $9 \%$, and on other goods was $15.8 \%$. 
Elasticities in the central case model specification are set as follows. There are no available estimates of elasticities for China either on the demand or production sides. We set the substitution elasticities in demands between domestic and imported commodities at 1 in both countries. We later use senstitivity analysis to change this value. The substitution elasticities between two domestic goods in each country we set at 0.5 and the substitution elasticities between the two imported goods in each country are also set at 0.5. For China's SOE manufacturing sector, first order conditions imply no value directly for the exponent in the production function. We assume a value of $\alpha_{M}^{1}=0.4$, which we loosely justify as the share of labor in total manufacturing output from the NBS (China's National Bureau of Statistics) data, which in the competitive (rather than the SOE ) case. This yields a value of $\varphi_{M}^{1}$ from equation (2). We also perform sensitivity analysis around this setting.

Table 1

Base Case Data in 2006 for China and ROW used in Calibrating the Model

\begin{tabular}{|c|c|c|c|c|c|c|}
\hline $\begin{array}{c}\text { China } \\
\text { (in billion } \mathrm{RMB}^{* 2} \text { ) }\end{array}$ & $\begin{array}{l}\text { Value of } \\
\text { Production }\end{array}$ & $\begin{array}{l}\text { Value of } \\
\text { labor input }\end{array}$ & $\begin{array}{c}\text { Value of } \\
\text { Consumption }\end{array}$ & $\begin{array}{l}\text { Exports to } \\
\text { ROW }\end{array}$ & $\begin{array}{c}\text { Import from } \\
\text { ROW }\end{array}$ & $\begin{array}{l}\text { Net } \\
\text { trade }\end{array}$ \\
\hline Manufacture & 1293.83 & 1293.83 & 377.81 & 916.02 & 604.33 & 311.69 \\
\hline Other Sector & 1364.05 & 1130.68 & 1311.13 & 52.92 & 187.13 & -134.21 \\
\hline Surplus & 177.47 & & & & & \\
\hline Exchange rate & $1: 1$ & & & & & \\
\hline $\bar{m}_{1}$ & 2657.88 & & & & & \\
\hline $\begin{array}{c}\text { ROW } \\
\text { (in billion US \$) }\end{array}$ & $\begin{array}{l}\text { Value of } \\
\text { Production }\end{array}$ & $\begin{array}{c}\text { Value of } \\
\text { labor input }\end{array}$ & $\begin{array}{c}\text { Value of } \\
\text { Consumption }\end{array}$ & $\begin{array}{l}\text { Exports } \\
\text { to China }\end{array}$ & $\begin{array}{l}\text { Import from } \\
\text { China }\end{array}$ & $\begin{array}{l}\text { Net } \\
\text { trade }\end{array}$ \\
\hline Manufacture & 12436.77 & 1979.12 & 11832.44 & 604.33 & 916.02 & -311.69 \\
\hline Other Sector & 36426.56 & 7074.27 & 36239.43 & 187.13 & 52.92 & 134.21 \\
\hline Surplus & -177.47 & & & & & \\
\hline Exchange rate & 1:1 & & & & & \\
\hline $\bar{m}_{2}$ & 49040.8 & & & & & \\
\hline
\end{tabular}

\footnotetext{
${ }^{2}$ We construct an artificial Chinese currency unit, $\mathrm{RMB}^{*}$, we set it as $\mathrm{RBM}^{*}=7.972 \mathrm{RMB}$, which is the exchange rate of the US dollar to Renminbi in 2006, this implies that 1 unit $R M B^{*}$ equals 1 US dollar. This convention is adapted so that in calibration all equilibrium prices will be unity.
} 
Table 2 reports the parameter values in production and preferences generated by calibration. When used in model solution these regenerate the benchmark dataset in Table 1 as an equilibrium.

Table 2

Model Parameterizations Generated by Calibration to the 2006 Benchmark Data

\begin{tabular}{|c|c|c|c|c|}
\hline \multicolumn{5}{|c|}{ A. Parameters in Production Functions } \\
\hline & \multicolumn{2}{|c|}{ China } & \multicolumn{2}{|c|}{ Rest of the World } \\
\hline & $\begin{array}{c}\text { Technology } \\
\text { coefficient } \varphi\end{array}$ & $\begin{array}{r}\text { exponent on } \\
\text { labor input } \alpha\end{array}$ & $\begin{array}{l}\text { Technology } \\
\text { coefficient } \varphi\end{array}$ & $\begin{array}{l}\text { exponent on } \\
\text { labor input } \alpha\end{array}$ \\
\hline \multirow{2}{*}{$\begin{array}{l}\text { Manufacturing } \\
\text { Other Sector }\end{array}$} & 102.379 & 0.405 & 3716.421 & 0.159 \\
\hline & 4.017 & 0.829 & 6513.066 & 0.194 \\
\hline \multicolumn{5}{|c|}{ B. Parameters in Nested CES Utility Functions } \\
\hline & \multicolumn{2}{|c|}{ China } & \multicolumn{2}{|c|}{ Rest of the World } \\
\hline \multicolumn{5}{|c|}{ Shares of Domestic and Import composite goods } \\
\hline & Domestic Produced & Imports & Domestic Produced & Imports \\
\hline & 0.659 & 0.341 & 0.979 & 0.021 \\
\hline \multicolumn{5}{|c|}{ Shares of manufacturing and other goods } \\
\hline & Domestic Produced & Imports & Domestic Produced & Imports \\
\hline Manufacturing & 0.077 & 0.908 & 0.096 & 0.996 \\
\hline Other Sector & 0.923 & 0.092 & 0.904 & 0.004 \\
\hline
\end{tabular}




\section{Numerical Analysis of Different Liberalization Policies in China}

We have used our calibrated model to simulate the impacts of various forms of economic liberalization policies on welfare, trade flows, and the trade surplus and on production. The liberalization policies include tariff elimination, a freely floating exchange rate, and SOE reform. Results are presented in Table 3 to Table 6 . We reports impacts on welfare using Hicksian money metric measures of welfare change. We calculate these as \% of GDP.

These results suggest that SOE reform and a freely floating exchange rate have more impact on China's welfare than tariff liberalization using 2006 data. RMB appreciation and an increase in China's money stock reduces China's trade surplus as would be expected. But impacts on exports are small. Most of the impact is on imports. For trade flows, in the traditional competitive model, trade liberalization influences both imports and exports, while in our model, with an endogenously determined trade surplus, tariff liberalization has no effect on exports. Impacts instead are on imports and the trade surplus. SOE reform of China's manufacturing sector significantly decreases the production of China's manufacturing sector and increases the production of China's other sectors.

In Table 3, we use our central model specification to analyze the impacts of three different policy elements in liberalization. For tariff elimination, we eliminate the tariff on both China's manufacturing and other sectors. In exchange rate policy, we freely float China's exchange rate and the trade surplus becomes zero. For SOE reform, we assume China's manufacturing sector changes from SOEs to competitive enterprises.

The first column of Table 3 reports the impacts of China's different economic liberalization policies on welfare using Hicksian CV measures. Welfare impacts using Hicksian EVs are similar and so in the tables, we only report the results for CVs. The most effective policy to improve China's welfare is SOE reform, the welfare impact on China is $12.212 \%$ of GDP, freely floating exchange is also effective with a welfare impact of $11.093 \%$ of GDP, but for tariff elimination the welfare impact on China is only 3.124\% of GDP. 
In the second column of Table 3, we report the impacts of different Chinese liberalization policies on trade flows. With a freely floating exchange rate, China's imports increase in value terms by around $22 \%$. The increase of the imports of manufacturing and other sectors are similar at nearly 22\%. For tariff elimination, China's imports increase in value terms by over $10 \%$. Manufacturing imports increase by $9.885 \%$ and the other sector imports increase by $12.937 \%$. For SOE reform, the impact on China's imports is very small, only $-0.051 \%$. In this model specification, the impact of all liberalizations on exports is very small. The endogenously determined trade surplus acts as a buffer adjusting to the policy change so that imports change sharply with little change in exports.

In the third column of Table 3, we report the impacts of alternative Chinese liberalization policies on production. SOE reform decreases production in China's manufacturing sector by over $16 \%$ in quantity terms, and increases the production of China's other sectors by $29 \%$ in quantity terms. Under a freely floating exchange rate, the production of China's manufacturing sector decreases by $3 \%$ in quantity terms, and the production of China's other sectors increases by $6 \%$. Tariff elimination has little effect on China's production since exports do not respond. 
Table 3

Welfare, Trade and Production Impacts of Model Based

Evaluations of Alternative Liberalizations

(Model with SOE average Product Labor Pricing and Monetary non-Neutralities / Trade Surpluses)

(Substitution elasticity between domestic and imported goods $=1, \alpha_{M}^{1}=0.4$ )

\begin{tabular}{|c|c|c|c|c|c|c|c|c|c|c|}
\hline & \multicolumn{2}{|c|}{$\begin{array}{l}\text { Welfare Impact as \% GDP } \\
\text { (Hicksian Measure) }\end{array}$} & \multicolumn{3}{|c|}{ \% Change in China’s imports } & \multirow{2}{*}{$\begin{array}{l}\text { \% Change in } \\
\text { China’s exports }\end{array}$} & \multicolumn{4}{|c|}{ \% Change in production } \\
\hline & China & ROW & Total & Manufacture & Other Sector & & China-Man & $\begin{array}{l}\text { China- } \\
\text { Other }\end{array}$ & $\begin{array}{l}\text { ROW- } \\
\text { Man }\end{array}$ & $\begin{array}{l}\text { ROW- } \\
\text { Other }\end{array}$ \\
\hline 1.Tariff Elimination & $3.124 \%$ & $-0.164 \%$ & $10.607 \%$ & $9.885 \%$ & $12.937 \%$ & $0.000 \%$ & $0.000 \%$ & $0.000 \%$ & $0.085 \%$ & $-0.029 \%$ \\
\hline $\begin{array}{l}\text { 2.Freely Floating } \\
\text { Exchange rate }\end{array}$ & $11.093 \%$ & $-0.517 \%$ & $22.237 \%$ & $22.431 \%$ & $21.610 \%$ & $-0.010 \%$ & $-3.178 \%$ & $6.248 \%$ & $0.201 \%$ & $-0.069 \%$ \\
\hline 3. SOE reform & $12.212 \%$ & $-0.468 \%$ & $-0.051 \%$ & $-0.051 \%$ & $-0.050 \%$ & $0.092 \%$ & $-16.716 \%$ & $29.007 \%$ & $0.000 \%$ & $0.000 \%$ \\
\hline
\end{tabular}


In Table 4 we present results from the three different forms of liberalization using three different models: the model with both SOE pricing and non-neutral money as used for Table 3, a model with only SOE pricing (neutral money) and a classical competitive model with neither of these features. Our purpose is to compare the welfare, trade and production impacts of alternative liberalizations across models to gauge how important elements of Chinese economic structure are for policy evaluation.

We see large difference among the results form these three models. For tariff elimination, in the competitive model, China's welfare decreases by $-1.002 \%$ of GDP due to an adverse term of trade effect. Adding SOE pricing and keeping money neutral increases the negative impact on China's welfare to $-1.581 \%$ as the terms of trade effects intensify. But in the model with SOE pricing and non-neutral money, China's welfare increases by $3.124 \%$ of GDP. In this model, tariff elimination has little effect on exports, since most of the impact is directed to the surplus, while in competitive model and model with only SOE pricing, the effects of tariff elimination on imports and exports are similar. For SOE reform, the non-neutral money model shows a welfare gain of $12.212 \%$ of GDP and the neutral money model shows an even higher welfare gain of $15.825 \%$ of GDP. The latter model results show that SOE reform has a significant effect on China's imports (41.580\%) and exports (31.561\%). 
Table 4

Comparing Welfare, Trade and Production Impacts of

Alternative Liberalizations Across Models

(Substitution elasticity between domestic and imported goods=1, $\alpha_{M}^{1}=0.4$ )

\begin{tabular}{|c|c|c|c|c|c|c|c|c|c|c|c|c|}
\hline & \multicolumn{4}{|c|}{$\frac{\text { Model with SOE pricing and }}{\text { non-neutral money }}$} & \multicolumn{4}{|c|}{$\begin{array}{l}\frac{\text { Model with only SOE pricing }}{\text { (neutral money) }} \\
\text { neul }\end{array}$} & \multicolumn{4}{|c|}{$\frac{\text { Competitive }}{\text { Model }}$} \\
\hline & \multicolumn{2}{|c|}{$\begin{array}{l}\text { Welfare Impact } \\
\text { as \% GDP } \\
\text { (Hicksian Measure) }\end{array}$} & \multirow{2}{*}{$\begin{array}{l}\text { \% Change in } \\
\text { China's } \\
\text { imports }\end{array}$} & \multirow{2}{*}{$\begin{array}{l}\text { \% Change in } \\
\text { China's } \\
\text { exports }\end{array}$} & \multicolumn{2}{|c|}{$\begin{array}{l}\text { Welfare Impact as \% GDP } \\
\text { (Hicksian Measure) }\end{array}$} & \multirow{2}{*}{$\begin{array}{l}\text { \% Change in } \\
\text { China's } \\
\text { imports }\end{array}$} & \multirow{2}{*}{$\begin{array}{l}\text { \% Change } \\
\text { in China's } \\
\text { exports }\end{array}$} & \multicolumn{2}{|c|}{$\begin{array}{l}\text { Welfare Impact as \% } \\
\text { GDP } \\
\text { (Hicksian Measure) }\end{array}$} & \multirow{2}{*}{$\begin{array}{l}\text { \% Change in } \\
\text { China's } \\
\text { imports }\end{array}$} & \multirow{2}{*}{$\begin{array}{c}\text { \% Change } \\
\text { in China's } \\
\text { exports }\end{array}$} \\
\hline & China & ROW & & & China & ROW & & & China & ROW & & \\
\hline $\begin{array}{l}\text { 1.Tariff } \\
\text { Elimination }\end{array}$ & 3. $124 \%$ & $-0.164 \%$ & $10.607 \%$ & $0.000 \%$ & $-1.581 \%$ & $0.041 \%$ & 7. $317 \%$ & 5. $554 \%$ & $-1.022 \%$ & $0.061 \%$ & 8. $709 \%$ & 7. $114 \%$ \\
\hline $\begin{array}{l}\text { 2.Freely Floating } \\
\text { Exchange rate }\end{array}$ & 11. $093 \%$ & $-0.517 \%$ & $22.237 \%$ & $-0.010 \%$ & - & - & - & - & - & - & - & - \\
\hline 3. SOE reform & $12.212 \%$ & $-0.468 \%$ & $-0.051 \%$ & $0.092 \%$ & $15.825 \%$ & $-0.641 \%$ & $41.580 \%$ & $31.561 \%$ & - & - & - & - \\
\hline
\end{tabular}


Table 5 then reports more detailed analyses of alternative liberalization impacts using our central case model. In the trade policy component, we first eliminate only tariffs on manufactures, and then eliminate only other sector tariffs. In monetary policy, we first consider RMB appreciation of 5\%,10\% respectively with a fixed money stock in both China and the Rest of the World, then we fix the RMB exchange rate and increase the money stock in China by $5 \%$ and $10 \%$ respectively.

Results in Table 5 show that monetary policy again seemingly has more impact than tariff liberalization on China's welfare , trade and production, while Renminbi appreciation and increasing monetary stock have similar impacts. With RMB appreciation of $5 \%$ and $10 \%$, China's welfare gains are $4.215 \%$ and $8.039 \%$ of GDP respectively, while with an increase in China's money stock of $5 \%, 10 \%$, China's welfare gains are $4.224 \%, 8.110 \%$ of GDP respectively, and elimination only of China's manufacturing tariffs leads to China's welfare gains of 1.986\% of GDP. Elimination of only other sector tariffs leads to Chinese welfare gains by $1.129 \%$ of GDP. In the base model; tariff liberalization and monetary policy have little impact on exports. The largest impact is on imports and the surplus. With RMB appreciation of 5\% and 10\%, China's imports increase by $8.283 \%, 17.487 \%$ respectively, with increase in China's monetary stock by $5 \%, 10 \%$, China's imports increase by $7.869 \%, 15.738 \%$ respectively, and elimination only of China's manufacturing tariffs leads to a Chinese import increase of $6.756 \%$. Elimination only of other sector tariffs leads to a Chinese import increase of 3.613\%. Trade policy has little effect on production, while under Renminbi appreciation and an increase in China's monetary stock China's manufacturing production decreases and China's other sector production increases. 
Table 5

More Detailed Analysis of Alternative Liberalization Impacts

(Model with SOE average Product Labor Pricing and Monetary non-Neutralities/Surpluses)

(Substitution elasticity between domestic and imported goods $=1, \quad \alpha_{M}^{1}=0.4$ )

\begin{tabular}{|c|c|c|c|c|c|c|c|c|c|c|}
\hline & \multicolumn{2}{|c|}{$\begin{array}{l}\text { Welfare Impact as \% GDP } \\
\text { (Hicksian Measure) }\end{array}$} & \multicolumn{3}{|c|}{ \% Change in China’s imports } & \multirow{2}{*}{$\begin{array}{l}\text { \% Change in } \\
\text { China's exports }\end{array}$} & \multicolumn{4}{|c|}{$\%$ Change in production } \\
\hline & China & ROW & Total & Manufacture & Other Sector & & China-Man & $\begin{array}{l}\text { China- } \\
\text { Other }\end{array}$ & $\begin{array}{l}\text { ROW- } \\
\text { Man }\end{array}$ & $\begin{array}{l}\text { ROW- } \\
\text { Other }\end{array}$ \\
\hline $\begin{array}{l}\text { 1.Elimination only } \\
\text { Manufacturing tariffs }\end{array}$ & $1.986 \%$ & $-0.103 \%$ & $6.756 \%$ & 7. $894 \%$ & 3. $081 \%$ & $0.000 \%$ & $0.000 \%$ & $0.000 \%$ & $0.076 \%$ & $-0.026 \%$ \\
\hline $\begin{array}{l}\text { 2.Elimination only other } \\
\text { sector tariffs }\end{array}$ & 1. $129 \%$ & $-0.057 \%$ & $3.613 \%$ & $1.788 \%$ & $9.505 \%$ & $0.000 \%$ & $0.000 \%$ & $0.000 \%$ & $0.008 \%$ & $-0.003 \%$ \\
\hline $\begin{array}{l}\text { 3. } 5 \% \text { Renminbi } \\
\text { appreciation }\end{array}$ & $4.215 \%$ & $-0.194 \%$ & $8.283 \%$ & $8.347 \%$ & 8. $074 \%$ & $-0.004 \%$ & $-1.256 \%$ & $2.514 \%$ & $0.075 \%$ & $-0.026 \%$ \\
\hline $\begin{array}{l}\text { 4. } 10 \% \text { Renminbi } \\
\text { appreciation }\end{array}$ & 8. $039 \%$ & $-0.407 \%$ & $17.487 \%$ & $17.634 \%$ & $17.011 \%$ & $-0.008 \%$ & $-2.548 \%$ & 5. $040 \%$ & $0.158 \%$ & $-0.054 \%$ \\
\hline $\begin{array}{l}\text { 5. } 5 \% \text { increase in China's } \\
\text { monetary stock }\end{array}$ & $4.224 \%$ & $-0.185 \%$ & 7. $869 \%$ & 7. $930 \%$ & 7. $672 \%$ & $-0.004 \%$ & $-1.195 \%$ & $2.394 \%$ & $0.072 \%$ & $-0.024 \%$ \\
\hline $\begin{array}{l}\text { 6. } 10 \% \text { increase in China's } \\
\text { monetary stock }\end{array}$ & $8.110 \%$ & $-0.367 \%$ & $15.738 \%$ & $15.868 \%$ & $15.316 \%$ & $-0.007 \%$ & $-2.310 \%$ & $4.580 \%$ & $0.143 \%$ & $-0.049 \%$ \\
\hline
\end{tabular}


Three parameters in the model are crucial for these results. One is the top level trade elasticities; a second is the bottom level trade elasticities, the third is $\alpha_{M}^{1}$ in the production function of China's SOE manufacturing sector. We thus perform sensitivity analyses on the results in Table 3 by varying these three parameters.

Table 6 provides the results. The welfare effect of tariff elimination is very sensitive to the top level elasticities used, while changing the bottom level trade elasticities has little impact on welfare effects of tariff elimination. With varying $\alpha_{M}^{1}$ the welfare impacts of trade elimination and freely floating exchange rates change greatly. When the $\alpha_{M}^{1}$ changes from 0.4 to 0.75 , the welfare impacts of tariff elimination changes from $3.124 \%$ to $11.979 \%$. The welfare impact of freely floating exchange rate changes from $11.093 \%$ to $17.386 \%$, the welfare effect of SOE reform changes from $12.212 \%$ to $14.630 \% . B u t$ while results are elasticity dependent, the theme of results that departures from the classical competitive model matters greatly for results remains. 
Table 6

Sensitivity Analyses of the Results on the Impacts of Alternative Liberalizations in Table 3

(Model with SOE average Product Labor Pricing and Monetary non-Neutralities/Surpluses)

\begin{tabular}{|c|c|c|}
\hline & \multicolumn{2}{|c|}{$\begin{array}{c}\text { Welfare Impact as \% GDP } \\
\text { (Hicksian Measure) }\end{array}$} \\
\hline & China & ROW \\
\hline \multicolumn{3}{|l|}{ 1.Tariff Elimination } \\
\hline Central Case & 3. $124 \%$ & $-0.164 \%$ \\
\hline $1 / 2$ top level trade elasticities & $0.498 \%$ & $-0.081 \%$ \\
\hline Increase top level trade elasticities by $50 \%$ & $5.220 \%$ & $-0.244 \%$ \\
\hline $1 / 2$ bottom level trade elasticities & 3. $065 \%$ & $-0.161 \%$ \\
\hline Double bottom level trade elasticities & 3. $173 \%$ & $-0.166 \%$ \\
\hline Set production exponent in SOE sector to 0.75 & $11.979 \%$ & 8. $979 \%$ \\
\hline \multicolumn{3}{|l|}{ 2.Freely Floating Exchange rate } \\
\hline Central Case & $11.093 \%$ & $-0.517 \%$ \\
\hline $1 / 2$ top level trade elasticities & $6.074 \%$ & $-0.309 \%$ \\
\hline Increase top level trade elasticities by $50 \%$ & $11.471 \%$ & $-0.792 \%$ \\
\hline $1 / 2$ bottom level trade elasticities & $9.556 \%$ & $-0.495 \%$ \\
\hline Double bottom level trade elasticities & $9.882 \%$ & $-0.543 \%$ \\
\hline Set production exponent in SOE sector to 0.75 & $17.386 \%$ & $8.643 \%$ \\
\hline \multicolumn{3}{|l|}{ 3.SOE Reform } \\
\hline Central Case & $12.212 \%$ & $-0.468 \%$ \\
\hline $1 / 2$ top level trade elasticities & $10.944 \%$ & $-0.050 \%$ \\
\hline Increase top level trade elasticities by $50 \%$ & $12.981 \%$ & $-1.370 \%$ \\
\hline $1 / 2$ bottom level trade elasticities & $12.433 \%$ & $-0.514 \%$ \\
\hline Double bottom level trade elasticities & $11.824 \%$ & $-0.383 \%$ \\
\hline Set production exponent in SOE sector to 0.75 & $14.630 \%$ & $9.226 \%$ \\
\hline
\end{tabular}




\section{Conclusions}

In this paper, we present numerical general equilibrium models of China with SOE behavior and non-neutral monetary structure that capture in a simplified form features of Chinese economic structure missing in conventional competitive models. We calibrate these models to 2006 data , and using the calibrated parameters, we analyze the impacts of three different liberalization policies on welfare and trade flows: tariff liberalization, a freely floating RMB exchange rate, and SOE reform. We note that China's economy is quite different from a typical OECD market economy, and so it is important to assess how far the competitive model now widely used in numerical simulation work on China can be misleading.

In our model, for the manufacturing SOE sector, we use the managerial control model of SOEs in Whalley \& Zhang(2006) and Fosse \& Raimondos-Møller(2009).In this SOEs are assumed to be under managerial control with managers politically appointed. Capital is assumed allocated freely to the SOE by state bank credit rationing with a recapitalization mechanism covering losses. We assume that enterprise managers seek to maximize personal gain from networking and political connections. We thus assume that enterprise managers seek to maximize enterprise size rather than profits. We add nonneutral monetary structure into our trade mode as in Wang \& Whalley(2007), to reflect the actual Chinese exchange rate and monetary regime. In this model monetary policy is non accommodative to the chosen fixed exchange rate, and at 2006 exchange rates this implies excess supply of foreign exchange and reserve accumulation.

Counterfactual model results show that large differences in policy impacts relative to a classical competitive model, including differences of sign. SOE reform and a freely floating Chinese exchange rate are more effective policies for improving China's welfare than tariff liberalization. Policies of RMB appreciation and increasing China's money stock reduce China's trade surplus. In the traditional competitive model, trade liberalization impacts both imports and exports, while in our central case model, with an endogenously determined trade surplus, trade liberalization has little effect on exports. Most of the impact is on imports and the trade surplus. SOE reform of China's manufacturing sector significantly decreases production of China's manufacturing sector and increases production in China's other sectors. 


\section{References}

Bigsten,A. ,X.X. Liu and J.H. Zheng (2002) ,“Efficiency, Technical Progress, and Best Practice in Chinese State Enterprises”, China Economic Quarterly 1: 521-540.

Cull R. , X.Li and C. Xu (2000) ,"Bureaucrats, State Banks, and the Efficiency of Credit Allocation: The Experience of Chinese State-Owned Enterprises”, Journal of Comparative Economics. 28: 131.

Fosse ,H. and P. Raimondos-Møller(2009), “Trade Liberalization with State-Owned Enterprises: The Case of Vietnam”, Paper Presented at CESifo Global Economy Area Meeting, Feb 27-28, 2009.

He,F. and Q.Y. Xu (2009), “China’s Exchange Rate Regime: Back to the Past.” Paper Presented at the 11th NBER-CCER Annual Conferences, Beijing, July 2009.

IMF (2005), “Asia-Pacific Economic Outlook”, International Monetary Fund, Washington, DC.

Kamada,K., and I.,Takagawa(2005), "Policy Coordination in East Asia and across the Pacific”, Bank of Japan Working Paper Series No. 05-E-4 (Bank of Japan, Tokyo).

Liu ,D.Q. (2002) "Managers in State-Owned Enterprises: Ability, Efforts, and Productive efficiency - A Case Study of the Iron and Steel Industry in China”, China Economic Quarterly 1:419-434.

Marquez, J., and J. Schindler( 2006), “Exchange Rate Effects on China’s Trade: An Interim Report”, Federal Reserve International Finance Discussion Paper No. 861 (Federal Reserve Board, Washington).

National Bureau of Statistics, PRC, “Chinese Statistical Yearbook”, www.stats.gov.cn

Park, C.(2005), “Coping with Global Imbalances and Asian Currencies”, www.adb.org

Thorbecke, W.(2006), "How Would an Appreciation of the Renminbi Affect the U.S. Trade Deficit with China?” Topics in Macroeconomics Volume 6, Issue 32006 Article 3, http://www.bepress.com/cgi/viewcontent.cgi?article=1454\&context=bejm

Willenbockel, D. (2006), "Structural Effects of a Real Exchange Rate Revaluation in China: A CGE Assessment”, MPRA Paper No. 920, http://mpra.ub.uni-muenchen.de/ 920/

Wang,L. and J.Whalley(2007), “The Impacts of Renminbi Appreciation on Trade Flows and Reserve Accumulation in a Monetary Trade Model”, NBER Working Paper No.13586.

Whalley,J. and S.M. Zhang(2006), "State-Owned Enterprise Behaviour Responses to Trade Reforms: Some Analytics and Numerical Simulation Results Using Chinese Data”, NBER Working Paper No.12780. 